\title{
Tanakpur Barrage \\ Thirteen Year Saga of the Nepal Canal Sill Level
}

\author{
SB Pun
}

\begin{abstract}
The Tanakpur Barrage was constructed by India in the 1980s on her territory on the Mahakali river, as an "alternative" to the aging 1920 Sarada barrage, to irrigate 1.61 million hectares of land in India. The sill level of the Tanakpur regulator for the Nepal canal is EL 245 meters, which is 3.5 meters (11.5 feet) higher than the sill level for the corresponding regulator for India. India stresses that specified quantity of water flow for Nepal will be assured as the pond level of the barrage for power generation will be maintained at EL 246.7 meters. Such promises were made on the Gandak barrage, which also has a powerhouse on the canal, but as the pond level was not maintained, Nepal never got the specified quantity of water from the Gandak barrage. Over the last 13 years, India has been totally deaf to Nepal's request to lower the sill level. Instead, India, argues that the Tanakpur regulator for Nepal was already "constructed in 1992 before the treaty." India's modus operandi, whether for the Farakka, Tanakpur, or Laxmanpur barrages or the Mahali Sagar, Rasiawal-Khurd-Lotan, Kalkalwa-Holiya bunds, has always been to construct first then, over the years, formalize it. Like many of the structures along the Indo-Nepal border, if Nepal does not take a firm stand then the Nepal canal sill level at Tanakpur is heading to be another fait accompli, for Nepal.
\end{abstract}

Key words: Tanakpur barrage, sill level, Sarada barrage, Mahakali Treaty, India, Nepal

\section{Background to the Mahakali Treaty}

Alternative to Sarada barrage

To comprehend the 13 year saga of the Nepal Canal Sill

1 Level from the head regulator of the Tanakpur barrage, it is necessary to recapitulate some of the more salient features that culminated in the Mahakali Treaty ratification. Acutely aware of the aging 1920 Sarada barrage that irrigates 1.61 million hectares ${ }^{1}$ of her land, India needed an "alternative"structuretoreplace it. R.C. Gupta, Additional Chief Engineer of India's Uttar Pradesh Irrigation Department, produced such an "alternative" (Lumsali 2053BS [1996AD]) in the December 1980 Note on Tanakpur-Banbasa Hydel Scheme on the Mahakali. Therein, Gupta noted that “...to avoid negotiations with Nepal for obtaining concurrence for execution.....the Barrage at Tanakpur has been sited at suitable location so that the barrage and its protection works be wholly in the Indian territory and the afflux of the pond created does not exceed the normal flood level in Nepal territory." This "entirely in India" Tanakpur barrage had hardly been operational when the monsoon furies of Mahakali river began to 'gnaw' its left bank and outflank the barrage.

\section{G.P. Koirala's Tanakpur MOU}

This 'gnawed' the Indian government so much that Indian Prime Minister Chandra Shekhar deemed it a necessity to request (Lumsali 2053BS [1996AD]) his counterpart, Nepal's Interim Prime Minister Krishna Prasad Bhattarai, on May 17, 1991 saying "...in view of the

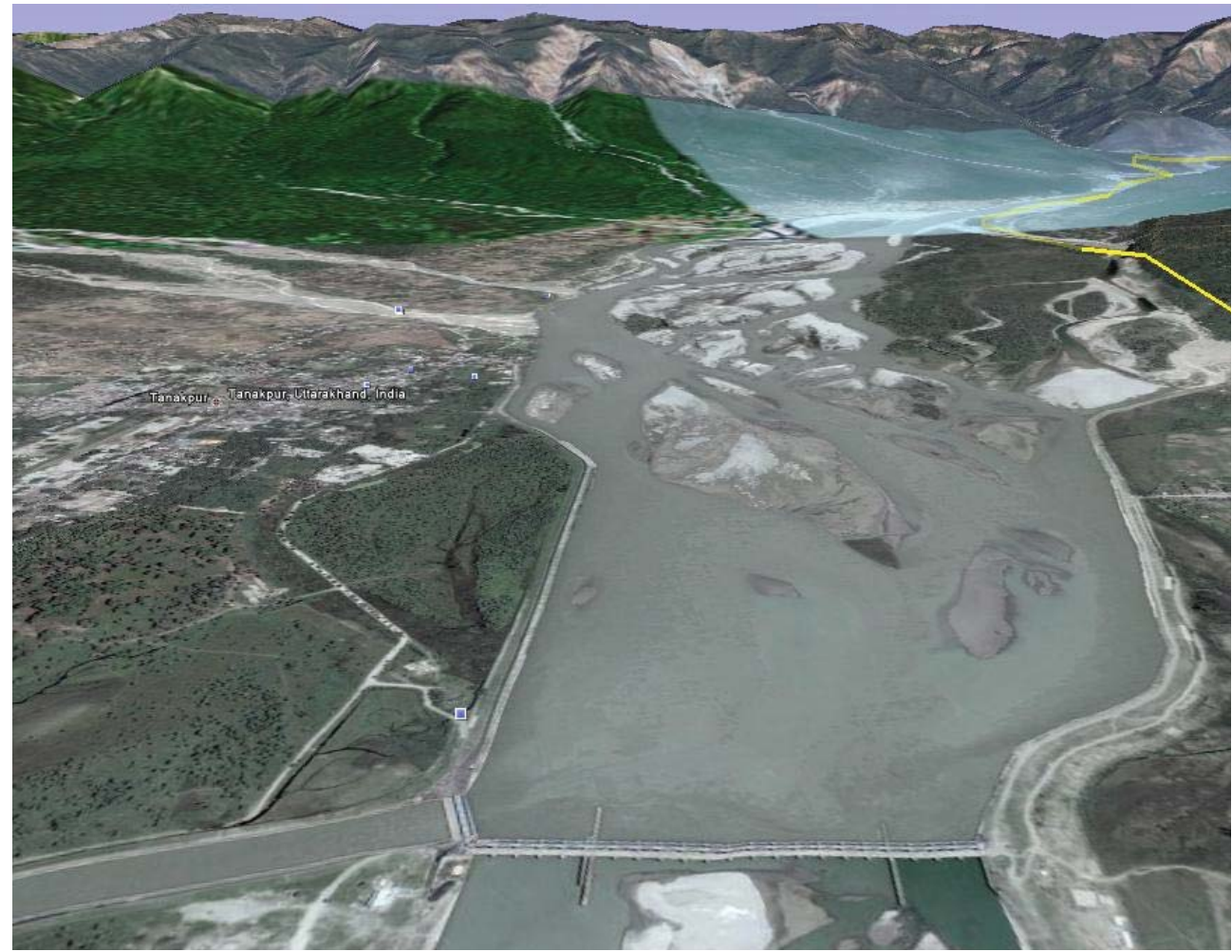

Tanakpur Barrage

Source: Google Earth 


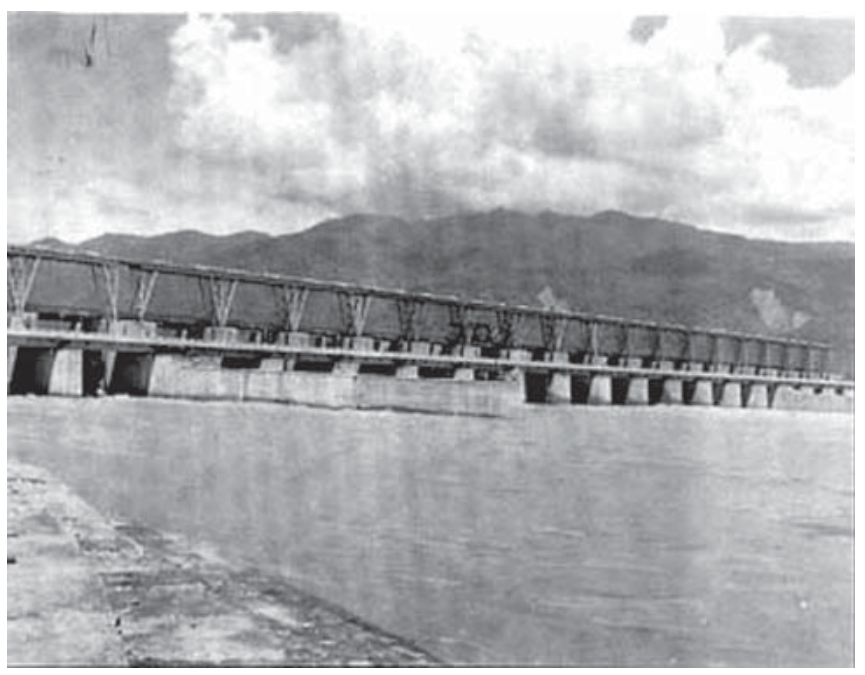

Tanakpur Barrage

approaching monsoon... tying the left afflux bund with high banks in the Nepalese territory... will bring a permanent solution." Nepal's concurrence, as initially envisaged by the Indian government, could not be avoided. An unwary new Prime Minister, G.P. Koirala, sans his Water Resources Minister and Secretary, attended the Delhi Durbar and leased Nepal's 11.9 hectares $^{2}$ of J imuwalandsto Indiafor the Tanakpur barrage through the J oint Commission ${ }^{3}$ decision dated December 5-6, 1991. So desperate was India for this J imuwa land that she pressed Prime Minister G.P. Koirala with "The availability of land for construction of bund will be affected in such a way by HMG/ $\mathrm{N}$ that the work could start by 15th of December 1991."4 India immediately closed the 'gnawed' left afflux bund of the Tanakpur barrage to the Nepalese high ground on a war footing.

\section{Madhav Kumar Nepal's package formula}

G.P. Koirala's government fell in July 1994 due to his own disgruntled Nepali Congress members of parliament (MPs) boycotting the voting of a government bill. To silence his 'rebel' MPs, Koirala called for mid-term election ${ }^{5}$ that resulted in a hung parliament with the CPN-UML as the largest single party, forming the minority government. Overtlykeen toresolvetheNepali Congressfueled Tanakpur Memorandum of Understanding (MOU) controversy, the CPN-UML government proposed the "Mahakali package formula" to India, comprised of Pancheshwar high dam of the future, Tanakpur barrage of the present, and Sarada barrage of the past, and called it the Integrated Mahakali Treaty. When the nine month old CPN-UML minority government got caught in a quagmire, refusing to tie up with the smaller 'tainted' parties to form a majority coalition government, the CPN-UML opted instead to dissolve the parliament and called for fresh election.

\section{S.B. Deuba's integrated Mahakali Treaty}

This call for fresh election was unfortunately quashed by the Supreme Court ${ }^{6}$ and the resurrected parliament led by the Nepali Congress formed a coalition government with Rashtriya Prajatantra Party and Sadhbhawana Party in September 1995. Events of historical importance then started to unfold fast. The new Prime Minister Sher Bahadur Deuba and his coalition brothers vigorously pursued the CP-UML's Mahakali package. In a matter of just four months, Nepal's Foreign Minister Dr P.C. Lohani and India's Foreign Minister Pranab Mukherjee signed the Mahakali agreement in Kathmandu on J anuary 29, 1996. Keen to trumpet the coalition government's achievement, Prime Minister Deuba, brushing aside Dr Baburam Bhattarai's (CPN-Maoist) 40 Point ultimatum (February 4, 1996), ${ }^{7}$ attended the Delhi Durbar and along with Prime Minister P.V. Narasimha Rao re-signed the historic Integrated Mahakali Treaty on February 12, 1996.

\section{Ratification of Mahakali Treaty amid chaos}

The CPN-Maoists fired their first shots on February 13, 1996 in Rolpa, Rukum and Sindhuli, along with Gorkha's Agriculture Development Bank and Kathmandu's Coca Cola factory. Deuba's coalition government, on the other hand, resorted to sending MPs to Bangkok for fake medical treatment, importing duty free expensive Pajeros for themselves and indulging in various ugly scams. It was truly an era of 'make hay while the sun shines'. In the midst of all this chaos, Prime Minister Deuba had the formidable task of ratifying the Mahakali Treaty. In this task, he was ably supported by two Panchayat era stalwarts, the Water Resources Minister Pashupati S.J.B. Rana ${ }^{8}$ and Foreign Minister Dr Prakash Chandra Lohani. It was unfortunate that the questions and answers on the Mahakali Treaty, instead of being traded ${ }^{9}$ between the Governments of Nepal and India, became very much of a domestic dohari (backand-forth) between Deuba's government and the CPNUML (Communist Party Nepal-United Marxist Leninist).

Luck, however, smiled on Deuba for the so called 'nationalist' CPN-UML party was badly fractured ${ }^{10}$ on the issue of the Mahakali Treaty ratification. J ust seven months after Deuba signed the Mahakali Treaty, voting took place (on September 20, 1996) and 220 MPs voted for the Nepali Congress led coalition government's motion for ratifying it. Only eight MPs voted against the motion, 31 MPs abstained with the Communist leader Man Mohan Adhikari absent and Speaker of the House, Ram Chandra Poudel, not required to vote. This meant an overwhelming 84\% MPs of the two houses of parliament voted for the ratification of the Mahakali Treaty. The unilaterally built Tanakpur barrage, a sore albatross hanging across India's neck was, with CPN-UML's assistance, subsumed and sanctified by the treaty. By comparison, though the Columbia River Treaty between USA and Canada was signed by US President Dwight D. Eisenhower and Canadian Prime Minister J ohn G. Diefenbaker on J anuary 17, 1961, the Canadian parliament took three years to ratify the treaty on J anuary 22, 1964 only after "improvements to the treaty and the sales of the downstream power benefits in the United States" were agreed upon between the two countries. ${ }^{11}$ 


\section{Mahakali Treaty and Nepal canal sill level}

Thirteen years have lapsed since that ratification by Nepal's parliament in September 1996. Public memory is short, but during that period nearly the same number of Prime Ministers graced Singha Durbar. What ails this treaty? What happened to Minister Pashupati S.J .B. Rana's promise to the Parliament to make the "sun rise from the west"? ${ }^{12}$ Where is Minister Dr Lohani's tidy sum of Rs 24 billion annually clicking into Nepalese coffers from sale of Pancheshwar electricity to India? ${ }^{13}$ Why isn't the Detailed Project Report (DPR), agreed to be ready in six months after treaty ratification, still not seen 'the light of the day"? ${ }^{14} \mathrm{An}$ attempt is made here to probe the lingering Nepal Canal Sill Level issue through the microscopic lens so that the persistent Indo-Nepal guerilla skirmishes over the border and larger macro-Mahakali Treaty issues can be better understood.

\section{Nepal Canal Sill Level from Tanakpur Barrage}

Tanakpur barrage sill level: for India EL 241.5 m, for Nepal EL 245 m

The Nepal Canal Sill Level is an extremely important issue for Nepal. India withdraws the Mahakali waters from the Tanakpur barrage at EL 241.5 meters. India, in a unilateral manner, conveniently provided an inlet for Nepal on the Tanakpur barrage at EL 245.0 meter - constructed before the signing of the treaty! This means that Nepal's canal intake is not at par with that of India. This also means Nepal is forced to withdraw the Mahakali waters 3.5 meters (11.55 feet) above that of India's intake. The main opposition political party, CPN-UML, constituted a Study Team that carried out an in-depth study of the Treaty on the Integrated Development of the Mahakali River so that the party could decided whether to ratify the treaty or not.

CPN-UML's Mahakali Treaty Study Team headed by K.P. Sharma (Oli)

The coordinator of the Mahakali Study Team was the UML stalwart, K.P. Sharma (Oli) who, on Bhadra 3, 2053 BS (17 August 1996 AD) put up 17 Mahakali treaty related questions to the Nepali Congress led government of Prime Minister S.B. Deuba. ${ }^{15}$ Though the Nepal Canal Sill Level did not figure in those 17 questions, it is certain that this was discussed as the K.P. Sharma (Oli) Study Report to his party included the Sill Level as an issue. Among K.P. Oli's 26 questions/comments, ${ }^{16}$ the following 10th comment/ answer was on the Nepal canal sill level from the Tanakpur barrage:

"10. The sill level of the water to be released from Tanakpur must be provided at 241.5 meter."

To which the Water Resources Minister (Pashupati S.J.B. Rana) replied: "His Majesty's Government has already requested the Government of India accordingly."

This wasin August/ September 1996 when Nepal's Water Resources Minister confirmed that India had already been requested to lower the Nepal Canal Sill Level to EL 241.5 meter, at par with India.

\section{1st J CWR meet: October, 2000}

Four years later, at the first Joint Commission on Water Resources (JCWR) meeting of October 1-3, 2000 at Kathmandu, theminutes on the Nepal Canal Sill Level read: "It was agreed that India will provide detailed information on the Tanakpur power house and the supply channel for further study and the matter will be finalized in the next JCWR meeting." ${ }^{\prime 17}$

\section{2nd J CWR meet: October, 2004}

Four years later, the second JCWR meeting was held in New Delhi on October 7-8, 2004. The following was recorded regarding the Nepal Sill Level:

"The Indian sideinformed that the detailed information on the Tanakpur Power House and the supply channel had been provided to the Nepalese side in accordance with the decision taken in the 1st meeting of JCWR. According to the Treaty, India is required to provide $28.35 \mathrm{~m}^{3} / \mathrm{sec}$. (1000 cusecs) of water during the wet season; i.e., from 15th May to 15 th October and $8.5 \mathrm{~m}^{3} / \mathrm{sec}$. (300 cusecs) during dry season; i.e., 16th October to 14th May. In order to fulfill this commitment, the Indian side pointed out that the head regulator on the left afflux bund of Tanakpur barrage with sill level at EL $245 \mathrm{~m}$ [thesill was already constructed before the treaty $]^{18}$ was capable of diverting the committed water supplies with pond level at EL $246.7 \mathrm{~m}$, which is always maintained (being the minimum level requirement) for the operation of the Tanakpur power house. ${ }^{19}$ The Nepalese side, however, contended that the sill level be lowered down to EL $241.5 \mathrm{~m}$ to match the sill level of head regulator on the right bank. After discussions, it was decided that a joint study including site inspection should be conducted to further study the issue and explore the possibility of finding a mutually acceptable solution and submit thejoint report by J anuary 2005. Based on the study a final decision be taken in the next meeting JCWR. The Composition of the joint study team is attached in Annex IV."

The argument "sill level already constructed before the treaty" is, indeed, a very lame excuse. That India would always maintain the pond level at EL 246.7 meter for the operation of Tanakpur powerhouse and that Nepal would receive the committed water supplies is very questionable. If India had maintained the water level at Gandak barrage, which also has a $15 \mathrm{MW}$ power plant downstream on the canal, then Nepal's western canal (for Nawalparasi District) would have received the promised quantity of water. But this has not been so. Similarly, India not only failed to provide the promised 850 cusecs of Gandak water from Gandak's eastern Don Canal for Parsa and Bara Districts, but irrigation to the Rautahat District command areas had to be curtailed. The story is the same for the Kosi Western canal where India promised to maintain the agreed water level in the canals and, having failed to do so, deprived Nepal of the committed water supplies. Indian records, in translating their words into actions, are very poor.

3rd JCWR meet: September/October, 2008

The minutes of the third JCWR meeting on the Sill 
Level held in Kathmandu from September 29 to October 1, 2008 recorded these three items:

"11. The Nepalese side reiterated that the Sill elevation of the head regulator, for releasing water from Tanakpur barrage to Nepal under Article 4 of Mahakali Treaty, be lowered to 241.5 meter."

"12. The Indian side assured the Nepalese side that pond level at Tanakpur barrage would be maintained at EL $246.7 \mathrm{~m}$ by project authorities at all times, as this was also required to operate the power plant and would in turn allow flow of committed discharge of water from Tanakpur barrage through existing regulator."

"13. The J CWR decided to direct concerned authorities to commence the construction of the $1.2 \mathrm{~km}$ of canal in Indian territory to match with the corresponding level of the ongoing Mahakali-III canal works in Nepalese territory, so that canal system could be operationalized."

Nepal's stand on the sill level is quite clear, but so is that of India. The see-saw tug-of-war of Nepal's reiteration and India's assurance continued. One is, however, not clear what is meant by "commence the construction of the $1.2 \mathrm{~km}$ of canal in Indian territory to match with the corresponding level of the ongoing Mahakali-III canal works." What is that matching corresponding level? Has Nepal already defaulted on this matching Mahakali-III canal level like the December 4-5, 1991 Tanakpur MOU?

\section{4th J CWR meet: March, 2009}

Thefollowingis theminutes of thefourthJ CWR meeting held in New Delhi on March 12-13, 2009 regarding the Sill level:

"5. JCWR was informed that NHPC [National Hydro Power Corporation $]^{20}$ is in the process of preparation of DPR for construction of $1.2 \mathrm{~km}$ long canal for supply of 1,000 cusecs of water from Tanakpur barrage to Nepal with a sill level of the Head regulator at EL $245.0 \mathrm{~m}$. It was informed by the Indian side that the canal alignment has been finalized but it needs some modification at junction point fixed by Nepalese side. Nepalese side agreed to modify the alignment of canal accordingly."

"6. Nepalese side, while reiterating their previous position on placing the sill level ${ }^{21}$ at EL $241.5 \mathrm{~m}$, requested that the discharge capacity of the canal in Indian portion may be increased to 56 cumecs (2,000 cusecs) to take care of a situation when Sarada barrage would become defunct. Indian side mentioned that the inlet portion of the Headregulator has already been constructed in 1992 for design discharge of 28 cumecs (1,000 cusecs) of water and it would not be advisable to dismantle the head regulator at this stage as it would require complete shut down of the Tanakpur H E Project. Further, a canal of higher capacity with lower discharge would result into siltation in the canal. Therefore, a new canal with separate head regulator would be considered as and when Sarada Barrage becomes non-functional."

India is abundantly clear that her NHPC will prepare the DPR for the Nepal canal at sill level EL $245.0 \mathrm{~m}$ from Tanakpur barrage. One now gets the impression that the
Nepal Canal Sill Level at EL 245.0 meter is finally a fait accompli. India, not only constructed the Tanakpur barrage unilaterally, but also had the foresight and courtesy to construct the 28 cumecs inlet for the Nepal Canal in 1992.22

\section{Conclusion}

\section{India's strategy}

The history of the Nepal Canal Sill Level originated with G.P. Koirala's Tanakpur MOU. During the Mahakali Treaty ratification turmoils, Nepal's Water Resources Minister, Pashupati SJ B Rana, gave a written reply to K.P. Sharma (Oli), coordinator of the CPN-UML Study Team, that Nepal had already asked India to provide the Nepal Canal Sill Level at EL 241.5 meter at par with that of India. Over the 13 year period, Nepal's requests by the Minister and Secretaries of Water Resources at the four JCWR meetings have all been kept in abeyance by India. Instead, India insists that the Nepal Canal Sill Level remains at EL 245 meters. The most recent 4th JCWR meeting of March 2009 reinforces that point: "J CWR was informed that NHPC is in the process of preparation of DPR for construction of $1.2 \mathrm{~km}$ long canal for supply of 1,000 cusecs of water from Tanakpur barrage to Nepal with a sill level of the Head regulator at EL $245.0 \mathrm{~m} . "$

Note the stress on the Nepal Canal Sill Level remaining put at EL 245.0 meter. Notealso India's refusal to entertain Nepal's other request that "...the discharge capacity of the canal in Indian portion may be increased to 56 cumecs $(2,000$ cusecs) to take care of a situation when Sarada barrage would become defunct." India constructed the Tanakpur barrage to replace the old outdated Sarada barrage. If the Sarada barrage does become "non-functional due to any cause" then India does not lose a drop of water as the Tanakpur canal feeds the Sarada canal. Nepal, however, would have to await the mercy of the Government of India to get another $1.2 \mathrm{~km}$ canal constructed in the Indian territory and another inlet constructed at the Tanakpur head regulator.

\section{Modus operandi and fait accompli}

Over the last 50 years, in stark contrast to colonial British-India, the Republic of India's modus operandi has always been 'Construct First' then wrangle over it in slow bureaucratic fashion to ultimately legalize it. India's unilaterally constructed Farraka barrage, opposed by Pakistan from early 1960s, became from May 1975 a fait accompli for Bangladesh. ${ }^{23}$ Similarly, the unilaterally constructed Tanakpur barrage of the 1980s became a fait accompli for Nepal from December 1991. Many predict that the unilaterally constructed Laxmanpur barrage, that the subcommittee of the Nepalese Parliament recommended demolition in July 2001, is heading to be another fait accompli for Nepal. ${ }^{24}$ There are countless unilateral actions of India - such as the Gaur submergence due to Bairgania Ring Bund, raising the 15-gated escape on the Mahali Sagar; constructing the $13.6 \mathrm{~km}$ Kalkalwa-Holiya afflux bund submerging 15 villages in Banke; and constructing 
the $47.5 \mathrm{~km}$ Kura-Ghoghi embankment submerging 18 villages in Rupandehi - that are all slated over the years to be Nepal's fait accompli.

\section{Large Indo-Nepal multipurpose projects}

The 269 meter high 3,300 MW Saptakoshi Dam at Barahchhetra, with a live storage of 9.4 billion cubic meters, that India in the 1950s hesitated and opted for the Hanumannagar Koshi barrage, is back "in focus this time in particular"25 with the August 18, 2008 Koshi embankment breaching at Kusaha. The tripartite (World Bank, India and Nepal) effort of the 1980s on the 270 meter high 10,800 MW Karnali Chisapani dam with a live storage of 16.2 billion cubic meters, for which over 250 Nepalese engineers were prepared from India's own Roorkee University, was stalled for strategic reasons, but has now been "re-activated". Despite the exchange of the Instruments of Ratification by the two countries on June 5, 1997, the 315 meter high 6,480 MW Pancheshwar dam, with a live storage of 6.6 billion cubic meters, slated to be completed in eight years, has been languishing for the last 13 years. With fresh water becoming scarce, particularly in the Gangetic basin, these three large projects alone will annually augment about 32.2 billion cubic meters of fresh water. India, so far, has shown no inkling of her intention to pay for the augmented fresh water that would be available only by submerging large tracts of Nepalese territory. Nepal, sadly, is mesmerized only by the 20,580 MW power export component, ${ }^{26}$ which India has been dangling as the carrot for the last five decades.

\section{Nepal's right to say no}

India refuses to lower the Nepal canal sill level from the Tanakpur barrage. This is a tiny gesture with no adverse consequences to India at all. Are such tiny refusals of India responsible for the 13-year stall of the Pancheshwar project? If this is so, then is there any logic to proceed with large Indo-Nepal multipurpose projects? Many Nepalese now believe that the time has come for Nepal to put her foot down and exercise her right to say NO. The readers need to know that the Nepalese and Indian canal sill levels from the 1920 British built Sarada barrage at Banbasa are at par, at the same EL 220.52 meter levels. Can it then be construed that the colonial imperial British-India wasn't that colonial after all? It is hoped the readers will make their own judgment on the 13 year Indo-Nepal dohari on the Nepal canal sill level!

Santa Bahadur Pun is the former Managing Director of Nepal Electricity Authority and in his closing years served as the Officer on the Special Duty at the Ministry of Water Resources, Government of Nepal. He writes on water and energy issues.

Corresponding address: santapun@ntc.net.np

\section{Notes}

1. This is the 1995 figure, but India now indicates 2.2 million hectares!

2. About 2.9 hectares un-submerged and about 9 hectares submerged lands at J imuwa.

3. So important was this December 5-6 1991 decision for India that it is enshrined as a preamble in the 1996 Mahakali Treaty. In retrospect, the wittier K.P. Bhattarai may have avoided that Tanakpur MOU decision.

4. This 15th December, 1991 is noteworthy. While Indian bulldozers started work in earnest at J imuwa, Prime Minister G.P. Koirala may not have even briefed his cabinet about this Jimuwa land (Nepal Gazette Vol. 41 No. 36). Notification about the Jimuwa land "made available to India" appeared only on December 29, 1991 (Bhasin 1994).

5. Political pundits now demur that if the Nepali Congress government had governed its full five year tenure, the World Bank could not have walked out of the 201 MW Arun-3 so irresponsibly, the political horse-trading culture would have been more muted, and perhaps Dr Baburam Bhattarai's 40 Point Demands may not have even surfaced.

6. Chief J ustice Bishwanath Upadhyaya's decision to resurrect the parliament was perhaps the final "Et tu, Brute?" stab on Nepal. This decision led to rampant corruption and horse trading, thus justifying Dr Baburam Bhattarai's 40 Point Demands and the CPN- Maoists' meteoric rise that bled Nepal for ten years. Prime Minister Manmohan Adhikari's call for going to the Nepalese people for fresh mandate would have curtailed the "ugly unnatural headed alliances."

7. Point 2, the so-called Integrated Mahakali Treaty concluded on 29 J anuary 1996 should be repealed immediately, as it is designed to conceal the disastrous Tanakpur Treaty and allows Indian imperialist monopoly over Nepal's water resources (Thapa and Sijapati 2003).

8. Both these stalwarts, ironically, must have opposed the Tanakpur barrage vehemently in their Panchayat hey-days. Pashupati S.J .B. Rana, great-grandson of Chandra Shumsher - signatory to Sarada Treaty - ironically played the lead role in Mahakali Treaty ratification.

9. When Foreign Minister Dr P.C. Lohani formally asked Indian ambassador, K.V. Rajan, on September 10, 1996 for the Government of India's views on the CPN-UML queries, the ambassador deftly replied "...highly inappropriate for us to comment on any aspect since ratification is purely Nepal's internal affair." Later, on September 19, 1996, he was to add that the government of India would be happy to discuss them ".. and reach mutually satisfactory understandings on them after ratification of the treaty, at the time of finalizing the DPR" (as quoted in the Mahakali Treaty Booklet of HMGN (His Majesty's Government of Nepal), Ministry of Water Resources, dated Kartik 29, 2053BS (November 13, 1996AD).

10. Of the $37 \mathrm{CPN}-\mathrm{UML}$ Central Committee members, 17 led by M.K. Nepal and K.P. Oli were for ratification, another 17 led by Bamdev Gautam and C.P. Mainali against, two (Rajendra Shrestha and Asta Laxmi Sakya) were neutral, and Manmohan Adhikari was absent, illustrating the deep division. Actually 55 sane CPN-UML MPs minuted that ratification of the treaty should be done only after amendments in the treaty. The party thus split into CPN-UML and CPN-ML (Lumsali 2053BS [1996AD]). 
11. The Columbia River Treaty booklet prepared by BC Hydro and Power Authority, dated October 1964. CPN-UML's 55 MPs, like C.P. Mainali, Bamdev Gautam, Sahana Pradhan, Hiranya Lal Shrestha, Prem Singh Dhami, et al, did minute at the parliamentary party meet that ratification of the treaty should be done only after amendments to the treaty. It was the M.K. Nepal and K.P. Sharma (Oli) camp that refused to listen.

12. See the Mahakali Treaty Booklet of HMGN, Ministry of Water Resources, dated Kartik 29, 2053BS (November 13, 1996AD).

13. Ibid.

14. This appropriate phrase was used at the Track Two Exercise on Mahakali Treaty by none other than Arjun Prasad Shrestha, former Project Chief of Pancheshwar Multipurpose Project.

15. Op. cit. (Mahakali Treaty Booklet).

16. Op. cit. (Mahakali Treaty Booklet).

17. www.mowr.gov.np. Displaying JCWR minutes on websites, hitherto a taboo, is indeed a commendable and welcome step of MOWR (Ministry of Water Resources), which was, in J une 2009, unfortunately unbundled into the Ministry of Irrigation (MOI) and Ministry of Energy (MOE). The government in 'transition', without any vetting or debates, resorted to this major surgery merely to satiate the greed of the political masters.

18. The bracketed observation is that of the writer.

19. At the 2003 Indo-Nepal Track Two Meet on Mahakali Treaty, India did concede that during the lean hydraulic cycle there may not be enough water on the river and so "India would be willing to compensate Nepal for the corresponding loss of energy benefits." This merely confirms that Nepal must be prepared for this eventuality and the Nepal Canal sill level must be lowered!

20. The NHPC is India's public sector undertaking (National Hydro Power Corporation).

21. This is the level India draws water for her canal from the Tanakpur barrage, a full 3.5 meter (11.6 feet) below that of Nepal's proposed canal! The capacity of the TanakpurBanbasa canal is said to be 566 cumecs when that of the old Sarada canal is only 356 cumecs; this enlarged canal capacity will be useful in justifying "without prejudice to their existing consumptive uses."

22. Prime Minister G.P. Koirala on December 5, 1991 had already signed away the so called Tanakpur MOU. The Nepal Gazette on Koirala's India visit came out only on December 29, 1991. This Gazette is silent on the Nepal canal sill level from Tanakpur barrage.

23. On April 18, 1975, Bangladesh permitted India to divert the Ganges river water to test-run the Farakka feeder canal only, but India continued this diversion unilaterally. Bangladesh did go to the UN about it, but ultimately it became a fait accompli on December 12, 1996 as the Treaty on Sharing of the Ganges Waters at Farakka.

24. Though the two governments constituted a High Level Technical Committee in March 2002 for both the Banke and Rupandehi Districts inundation problems, seven years have already lapsed. It is certain that both cases would get the fait accompli stamps ultimately.

25. India's Water Resources Minister, Professor Saif Uddin Soz, in his interview to BBC Nepali Service - Nepali Times No.418 (September 19-25, 2008).

26.The Government of Nepal constituted a 15-man Task Force (with S.N. Poudel as Coordinator, L.N. Bhattarai as Member Secretary, plusotherluminarieslikeR.L. Kayastha, DrG. Nepal, B. Pradhan, L.M Bhandari, S. Upadhyaya, Dr L.P. Devkota, G.L. Pradhan, A.K. Upadhyaya, A.R. Pande, A.K. Karki, S.B. Malla, U.K. Shrestha and Dr S.A. Mishra) on Mangsir 18, 2065BS (December 3, 2008AD) for the formulation of 10,000 MW in ten Years. This is the kind of hydropower and not Hydro psyche that we suffer from. The other wrong psyche that we suffered from but implemented is the unbundling in Asar 2066BS (J une 2009AD) of the Water Resources Ministry into Ministry of Irrigation and Ministry of Energy.

\section{References}

Bhasin, A.S., 1994, Nepal's Relations with India and China: Documents 1947-92, Delhi: Siba Exim, Pvt. Ltd.

Lumsali, Rishi, 2053BS, 'Mahakali Nadi bata Prapta Upalabdi ko Rakchhya Garaun, Thap Upalabdi ko Lagi Sangarsha Garaun (1996AD, Let us Protect Benefits from Mahakali River, Let us struggle for additional benefits), Kathmandu: Sunkoshi Press Thapa, D. and B. Sijapati, 2003, A Kingdom under Siege, Kathmandu: The Printhouse. 